ONLINE MUTATION REPORT

\title{
BRCA1:185delAG found in the San Luis Valley probably originated in a Jewish founder
}

\author{
I Makriyianni, N Hamel, S Ward, W D Foulkes, S Graw
}

J Med Genet 2005;42:e27 (http://www.jmedgenet.com/cgi/content/full/42/5/e27). doi: 10.1136/jmg.2004.029785

$\mathrm{T}$ hree BRCAl/2 mutations (185delAG and 5382insC in $B R C A 1$, and 617delT in BRCA2) are present in about $2.5 \%$ of the Ashkenazi Jewish population, ${ }^{1-4}$ and in $10-$ $12 \%$ of Ashkenazi Jewish women with breast cancer. ${ }^{5}$ Mutations that become common in a population are often explained by the presence of a "founder effect". This effect tends to exist when a population is established by a small group of ancestors. The members of the group are called founders and become isolated from the original population from which they are derived on account of geographical, cultural, or linguistic barriers. If this isolation persists, genetic drift can cause disease producing alleles present in the founders to become more frequent in subsequent generations.

The San Luis Valley (SLV) is a large, isolated valley situated on the border between New Mexico and Colorado. The first settlers were Spaniards of the de Oñate expedition in 1598, but today it has an admixed population descended from Native Americans, West Africans, and Europeans. ${ }^{6}$ A previous study in Colorado of breast cancer patients with SLV ancestry revealed the presence of a hereditary breast cancer mutation, BRCA1:185delAG. ${ }^{7}$ Many of these individuals came from areas of Spanish settlement in what is now northern New Mexico, an area known to have had a number of Spanish settlers with Jewish heritage. This population remained fairly coherent until the mid-1900s, which would have allowed the fixation of certain mutations in the population through the founder effect. $^{8}$

The 185delAG mutation (c.68_69del2) is a founder mutation in the Ashkenazi Jewish population and is the most common BRCAI mutation in this population, with a frequency of $1 \% .^{23}$ Markers flanking this mutation have conserved alleles among Ashkenazi carriers, allowing for the construction of a distinct, linked haplotype. ${ }^{4}$ In this study, we followed up on our original finding and set out to determine whether the BRCA1:185delAG mutation found in patients from the SLV is the same mutation found in Jewish patients, by testing seven nearby markers known to be conserved on the 185delAG Jewish haplotype.

All participants of this study identified themselves as Spanish/Latin American and denied any Jewish ancestry. Subjects 1-8 of the study were included in our previous study, where details of the family history can be found, ${ }^{7}$ and subjects 9-11 are new subjects who were seen at the same genetic counselling centres and underwent the same clinical testing as the rest of the subjects (table 1). All subjects have a strong family history of breast or ovarian cancer. Patients with breast or ovarian cancer satisfied the American Society of Clinical Oncologists genetic testing for cancer predisposition inclusion criteria before genetic mutation analysis. Myriad Genetics Laboratories Inc carried out the mutation analysis by direct genomic sequencing, and showed that all patients except patient 7 are carriers of the 185delAG mutation. We amplified DNA from these patients by radioactive polymerase chain reaction (PCR) and visualised the genotypes on a $6 \%$ polyacrylamide sizing gel.

\section{Key points}

- The BRCA1:185delAG mutation is a frequent founder mutation in the Ashkenazi Jewish population. This mutation was also observed in breast cancer patients from the San Luis Valley (SLV) of Colorado and New Mexico.

- Seven nearby markers known to be conserved on the 185delAG Jewish haplotype were tested to determine whether the SLV mutation shares an origin with the Jewish mutation, or whether it arose independently.

- All 185delAG mutation carriers were found to share the conserved allele at each of the seven loci tested.

- These results suggest that individuals in the SLV who carry the 185delAG mutation share a common ancestor with Jews who also carry this mutation.

Table 1 shows the genotypes of the subjects for each marker in reference to the conserved Jewish haplotype. We found that all 185delAG mutation carriers share a conserved allele at each of the seven loci tested. Moreover, subject 7, a non-carrier, does not have the conserved alleles at any of the loci. These results are consistent with the hypothesis that individuals in the SLV who carry the 185delAG mutation share a common ancestor with Jews who also carry this mutation. This finding suggests that individuals in this population have at least one ancestor of Jewish origin.

\section{COMMENT}

The BRCA1:185delAG mutation has previously been observed on different haplotypes in both Jewish and non-Jewish mutation carriers, which implies that the mutation arose more than once. ${ }^{49}$ However, the existence of only one haplotype in the Ashkenazi Jews indicates a single origin within this population. ${ }^{4}$ Two previous studies also found that non-Jewish populations of Hispanic origin segregate the 185delAG mutation with the Ashkenazi Jewish haplotype. One study was on a Spanish gypsy population and another on a Chilean family with no known Jewish ancestry. ${ }^{10}{ }^{11}$ Most recently, Weitzel et al found that BRCA1:185delAG is the most frequent deleterious BRCAl mutation in women of Hispanic origin living in Los Angeles. All patients with the BRCA1:185delAG mutation from this area also show conservation of the common Ashkenazi haplotype at markers centromeric to and throughout the BRCAl gene. ${ }^{12}$

The linked haplotype is commonly referred to as the "Ashkenazi Jewish haplotype" because it was originally identified and has been extensively studied in Ashkenazi Jews. ${ }^{413}$ However, this does not mean that the haplotype is unique to this population. Indeed, other non-Ashkenazi

Abbreviations: SLV, San Luis Valley 
Table 1 Genotypes of the San Luis Valley BRCA 1:185delAG mutation carriers

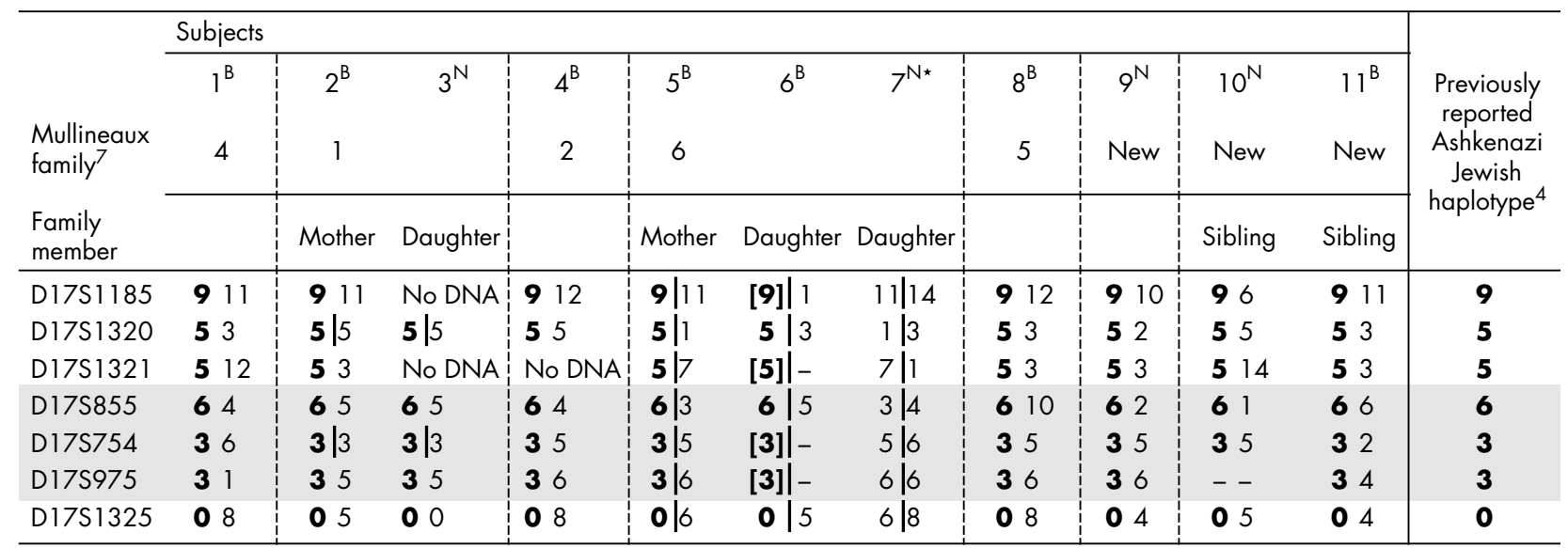

Subject with: B, breast cancer; N, no cancer.

The genotypes of the San Luis Valley patients for seven markers located within or near the BRCA1 gene (D17S1185, D17S1320, D17S1321, D17S855, D17S754 D17S975, D17S1325) ${ }^{4}$ are shown. Grey highlighted markers are located within the BRCA1 gene, thus closer to the 185 delAG mutation.

Vertical dashed lines separate families. Patients' genotypes for each marker are indicated in each column. Vertical bars: phased alleles. Bold numbers: haplotype of BRCA 1: 185delAG. Brackets: alleles inferred from family member haplotypes. Dashes indicate that the allele could not be determined (PCR did not work). No DNA: DNA was no longer available for testing at these markers.

*The mutation non-carrier.

†New subjects' family history details: subject 9: her mother, maternal grandmother and aunt had breast and ovarian cancer; subject 10: her mother and sister had breast and fallopian tube cancer and her maternal aunt has breast ovarian cancer; subject 11: another sister of subject 10.

Jewish populations also carry the 185 delAG mutation..$^{13}$ One possible interpretation of this finding is that the mutation could have arisen at an ancient time before the dispersion of Jews. However, Neuhausen et al determined that the mutation occurred around 1235 CE (90\% confidence interval ranging from 396 to $1536 \mathrm{CE}$ ) based on the $500 \mathrm{~kb}$ conserved region that they found centromeric to the mutation. ${ }^{4}$ Although one of our previous studies narrowed down the conserved region to $200 \mathrm{~kb}$, suggesting that the mutation is actually older, ${ }^{11}$ its origin is still likely more recent than the last dispersion of the Jews in the Diaspora, estimated to be around $70 \mathrm{CE} .{ }^{13}$ A second possibility that the mutation could have arisen after the divergence of the Jews and the "Ashkenazi" 185delAG alleles are a result of isolated population admixture. ${ }^{14}$ Ah Mew et al speculated that the Chilean family in their study most probably has Sephardic ancestry because the family established in Chile before the most recent Ashkenazi Jewish immigration to the Americas (late 1800s to early 1900s). ${ }^{11}{ }^{14}$ Sephardic Jews lived in Spain and Portugal until the Spanish Inquisition in the late 1400s; then they migrated to several regions around the world, including the Americas. ${ }^{14}$

Mullineaux et al speculate that the present day Hispanic population of the SLV descended from a core group of Spanish settlers in $1598 .^{7}$ We believe that a Sephardic Jewish member of the group introduced the mutation to the valley, although we cannot exclude the possibility that the founder of this mutation in the valley was Ashkenazi Jewish. For example, in 1648 the Westphalia agreement was signed between the Netherlands, Spain, and other European nations, ending 80 years of war. ${ }^{15}$ This resulted in increased movement between Europeans, and a Jewish settler of the valley could conceivably have come from anywhere in Europe, and thus could have been Ashkenazi. Nevertheless historical dates and the presence of the mutation in other Hispanic populations are evidence to support the view that the founder of the mutation in such populations was Sephardic. ${ }^{11}{ }^{14}$ In summary, it is our belief that the Jewish ancestor(s) of the SLV were also Sephardic in origin, as the De Oñate expedition arrived in 1598, close to the time of the
Spanish inquisition and considerably earlier than the recent Ashkenazi immigration to the Americas.

"Ashkenazi" founder mutations have also been observed in non-Ashkenazi Jewish populations in other syndromes. Examples of these are the mutations causing Bloom syndrome and Creutzfeldt-Jakob disease. Bloom syndrome is a rare autosomal recessive disorder that causes short stature, skin pigmentation anomalies, and immunodeficiency. ${ }^{16}{ }^{17}$ A study of Bloom patients of non-Ashkenazi origin in America revealed an "Ashkenazi" mutation, present on an Ashkenazi haplotype, in about 5\% of the patients. ${ }^{17}$ Patients of this subgroup are from Spanish speaking Catholic families that have resided in south western United States, Mexico, or El Salvador for several generations. This study also implies Jewish ancestry in these Spanish immigrants. Haplotype analysis of the $200 K$ PRNP mutation causing Creutzfeldt-Jakob disease also indicates a single origin of the mutation in Jewish populations. It was observed in $100 \%$ of patients from a Jewish population in Tunisia, in $47 \%$ of Libyan Jewish patients, and in $100 \%$, 33\%, and $43 \%$ of patients from non-Jewish populations of Spain, Italy, and Chile, respectively. ${ }^{18}$

The results of this and previous studies on non-Jewish populations support the presence of well known Ashkenazi Jewish founder mutations in non-Jewish individuals. Specifically, these studies illustrate the presence of Jewish ancestry in patients with a personal or familial history of breast cancer who identify themselves as having Spanish origins. $^{7101119}$ Future studies are necessary to evaluate the frequency of this mutation in the San Luis Valley population.
Authors' affiliations
I Makriyianni, Department of Human Genetics, McGill University, Montreal, Quebec, Canada
N Hamel, Department of Medicine, McGill University Health Centre, Montreal
W D Foulkes, Program in Cancer Genetics, Departments of Oncology and Human Genetics, McGill University
S Ward, University of Wyoming, Laramie, Wyoming, USA 
S Graw, Eleanor Roosevelt Institute, University of Denver, Denver, Colorado, USA

Competing interests: none declared

Correspondence to: Dr William D Foulkes, Montreal General Hospital, 1650 Cedar Avenue, Room L10-1 16, Montreal, Quebec, Canada H3G 1A4; william.foulkes@mcgill.ca

Received 7 December 2004

Revised version received 30 January 2005

Accepted 1 February 2005

\section{REFERENCES}

1 Oddoux C, Struewing JP, Clayton CM, Neuhausen S, Brody LC, Kaback M, Haas B, Norton L, Borgen P, Jhanwar S, Goldgar D, Ostrer H, Offit K. The carrier frequency of the BRCA2 6174delT mutation among Ashkenazi Jewish individuals is approximately 1\%. Nat Genet 1996;14:188-90.

2 Roa BB, Boyd AA, Volcik K, Richards CS. Ashkenazi Jewish population frequencies for common mutations in BRCA1 and BRCA2. Nat Genet 1996; 14:185-7.

3 Struewing JP, Abeliovich D, Peretz T, Avishai N, Kaback MM, Collins FS, Brody LC. The carrier frequency of the BRCA1 185delAG mutation is approximately 1 percent in Ashkenazi Jewish individuals. Nat Genet 1995; 11:198-200.

4 Neuhausen SL, Mazoyer S, Friedman L, Stratton M, Offit K, Caligo A, Tomlinson G, Cannon-Albright L, Bishop T, Kelsell D, Solomon E, Weber B Couch F, Struewing J, Tonin P, Durocher F, Narod S, Skolnick MH, Lenoir G Serova O, Ponder B, Stoppa-Lyonnet D, Easton D, King MC, Goldgar DE. Haplotype and phenotype analysis of six recurrent BRCA1 mutations in 61 families: results of an international study. Am J Hum Genet 1996:58:271-280.

5 Warner E, Foulkes W, Goodwin P, Meschino W, Blondal J, Paterson C, Ozcelik H, Goss P, Allingham-Hawkins D, Hamel N, Di Prospero L, Contiga V, Serruya C, Klein M, Moslehi R, Honeyford J, Liede A, Glendon G, Brunet JS, Narod S. Prevalence and penetrance of BRCA1 and BRCA2 gene mutations in unselected Ashkenazi Jewish women with breast cancer. J Natl Cancer Inst 1999;91:1241-7.

6 Bonilla CPE, Pfaff CL, Dios S, Marshall JA, Hamman RF, Ferrell RE, Hoggart CL, McKeigue PM, Shriver MD. Admixture in the Hispanics of the San Luis Valley, Colorado, and its implications for complex trait gene mapping. Ann Hum Genet 2004;68:139-53.
7 Mullineaux LG, Castellano TM, Shaw J, Axell L, Wood ME, Diab S, Klein C, Sitarik M, Deffenbaugh AM, Graw SL. Identification of germline 185delAG BRCA1 mutations in non-Jewish Americans of Spanish ancestry from the San Luis Valley, Colorado. Cancer 2003;98:597-602.

8 Tushar OL. In: The people of El Valle: a history of the Spanish colonials in the San Luis Valley, 3rd ed. Pueblo, Colorado: El Escritorio, 1997.

9 Xu CF, Chambers JA, Nicolai H, Brown MA, Hujeirat Y, Mohammed S, Hodgson S, Kelsell DP, Spurr NK, Bishop DT, Solomon E. Mutations and alternative splicing of the BRCA1 gene in UK breast/ovarian cancer families. Genes Chromosomes Cancer 1997; 18:102-10.

10 Diez O, Domenech M, Alonso MC, Brunet J, Sanz J, Cortes J, del Rio E, Baiget $M$. Identification of the 185delAG BRCA1 mutation in a Spanish Gypsy population. Hum Genet 1998; 103:707-8.

11 Ah Mew N, Hamel N, Galvez M, Al-Saffar M, Foulkes WD. Haplotype analysis of a BRCA1: 185delAG mutation in a Chilean family supports its Ashkenazi origins. Clin Genet 2002;62:151-6.

12 Weitzel JK, Blazer K, Nelson R, Lagos V, Ricker C, Herzog J, Neuhausen S. Prevalence of BRCA mutations and founder effect in high-risk Hispanic families in Southern California [abstract]. Presented at: Annual Meeting of the American Society of Human Genetics, 27 October 2004; Toronto, Ontario; http://www.ashg.org/genetics/ashg04s/index.shtml.

13 Bar-Sade RB, Kruglikova A, Modan B, Gak E, Hirsh-Yechezkel G, Theodor L, Novikov I, Gershoni-Baruch R, Risel S, Papa MZ, Ben-Baruch G, Friedman E. The 185 delAG BRCA1 mutation originated before the dispersion of Jews in the diaspora and is not limited to Ashkenazim. Hum Mol Genet 1998;7:801-5.

14 Ostrer H. A genetic profile of contemporary Jewish populations. Nat Rev Genet $2001 ; 2: 891-8$.

15 Online TBE. Peace of Westphalia. http://www.britannica.com/ebc/ article?tocld $=9382585,2005$

16 German J, Ellis N. Bloom syndrome. In: Vogelstein B, Kinzler KW, eds. The genetic basis of human cancer. New York: McGraw-Hill, 1998:301-15.

17 Ellis NA, Ciocci S, Proytcheva M, Lennon D, Groden J, German J. The Ashkenazic Jewish Bloom syndrome mutation blmAsh is present in non-Jewish Americans of Spanish ancestry. Am J Hum Genet 1998;63:1685-93.

18 Lee HS, Sambuughin N, Cervenakova L, Chapman J, Pocchiari M, Litvak S, Qi HY, Budka H, del Ser T, Furukawa H, Brown P, Gajdusek DC, Long JC, Korczyn AD, Goldfarb LG. Ancestral origins and worldwide distribution of the PRNP 200K mutation causing familial Creutzfeldt-Jakob disease. Am J Hum Genet 1999;64:1063-70.

19 Diez O, Osorio A, Robledo M, Barroso A, Domenech M, Cortes J, Albertos J, Sanz J, Brunet J, SanRoman JM, Alonso MC, Baiget M, Benitez J. Prevalence of BRCA1 and BRCA2 Jewish mutations in Spanish breast cancer patients. Br J Cancer 1999;79:1302-3. 